\title{
Pengaruh Entrepreneurship dan Market Oriented Terhadap Keunggulan Bersaing untuk Peningkatan Kinerja Online Shop UMKM
}

\author{
Uke Prajogo
}

STIE Malangkucecwara, Jl. Terusan Candi Kalasan, Malang Indonesia

\begin{tabular}{|c|c|}
\hline Info Artikel & ABSTRAK \\
\hline Riwayat Artikel & $\begin{array}{l}\text { Penelitian ini bertujuan mengetahui pengaruh market oriented } \\
\text { dan entrepreneurship terhadap keunggulan bersaing untuk }\end{array}$ \\
\hline Diterima: $15-12-2020$ & peningkatan kinerja online shop pada UMKM di Kota Malang. \\
\hline Direvisi: $25-12-2020$ & Jenis penelitian yang digunakan adalah explanatory research. \\
\hline Disetujui: 08-01-2021 & $\begin{array}{l}\text { Sampel dalam penelitian ini adalah } 84 \text { orang responden yang } \\
\text { menjadi pemilik UMKM diambil secara incidental sampling. }\end{array}$ \\
\hline Kata Kunci & yang digunakan adalah analisis regresi linier berganda, dimana \\
\hline Market Oriented; & $\mathrm{X}_{1}$ menunjuk pada variable entrepreneurship, $\mathrm{X}_{2}$ pada market \\
\hline Enterpreneurship; & oriented, $\mathrm{Y}_{1}$ pada keunggulan bersaing, dan $\mathrm{Y}_{2}$ pada kinerja \\
\hline Keunggulan Bersaing; & online shop. Berdasarkan hasil penelitian disimpulkan bahwa \\
\hline Kinerja Online Shop; & $\begin{array}{l}\text { market oriented dan entrepreneurship berpengaruh positif dan } \\
\text { signifikan terhadap keunggulan bersaing dan kinerja online } \\
\text { shop. Market oriented dan entrepreneurship yang lebih baik }\end{array}$ \\
\hline$\triangle$ Corresponding Author & akan meningkatkan keunggulan bersaing dan kinerja online \\
\hline $\begin{array}{l}\text { Uke Prajogo, } \\
\text { STIE Malangkucecwara, }\end{array}$ & $\begin{array}{l}\text { shop. Keunggulan bersaing berpengaruh positif dan signifikan } \\
\text { terhadap kinerja online shop. }\end{array}$ \\
\hline
\end{tabular}

Tel. +62 81235084536

ukeprajogo@stie-mce.ac.id

\section{PENDAHULUAN}

UMKM dengan variasi produknya terus tumbuh dan menjanjikan masa depan bagi Indonesia. Disisi lain, persoalan promosi dan kinerja online shop masih menjadi tantangan bagi UMKM. Produsen tidak bisa menunggu pembeli. Kreativitas saja tidak akan cukup masih sering produk yang baik tersebut sulit diakses oleh pembeli. Bahkan masih ada pembeli tidak tahu bahwa produk kreatif itu ada di Indonesia. Keberadaan internet saat ini digunakan sebagai e-dagang serta semakin memudahkan interaksi dengan pembeli diberbagai tempat dan waktu. Setiap kedutaan dan konsultan di mancanegara diminta terus menggencarkan promosi produk-produk industri Indonesia. Para pelaku industri harus memperhatikan kualitas, harga, ketepatan pengiriman dan kemasan. Indonesia mempunyai potensi besar dalam pasar kerajinan domestik maupun di dunia.

Tabel 1. Perkembangan usaha Mikro, Kecil, Menengah (UMKM) dan Usaha Besar tahun 1997,1998 dan 2012

\begin{tabular}{llllllll}
\hline \multirow{2}{*}{ No. } & \multirow{2}{*}{ Indikator } & \multicolumn{2}{c}{ Tahun 1997 } & \multicolumn{2}{c}{ Tahun 1998 } & \multicolumn{2}{c}{ Tahun 2019} \\
& & Jumlah & Pangsa (\%) & Jumlah & Pangsa (\%) & Jumlah & \multicolumn{1}{c}{ Pangsa (\%) } \\
\hline 1. & UMM & 39.765 .100 & 99,99 & 36.813 .578 & 100,00 & 56.534 .592 & 99,99 \\
2. & Usaha Besar & 2.027 & 0,01 & 1.831 & 0,00 & 4.968 & 0,01 \\
\hline
\end{tabular}

Sumber: BPS dan Depkop, 2019

Tabel 1 dibuktikan bahwa krisis tahun 1998 memberikan pengaruh yang besar pada 
jumlah Usaha Mikro Kecil Menengah (UMKM) dan usaha besar. Akan tetapi, meski jumlah UMKM juga menurun di tahun 1998, pangsa pasar sepenuhnya dikuasai oleh UMKM dan usaha besar kehilangan pangsa pasarnya karena jumlah UMKM jauh lebih banyak daripada jumlah usaha besar yaitu sebesar 36.813.578 unit. Bahkan sampai tahun 2012, UMKM masih menguasai pangsa pasar di Indonesia sebesar 99,99\% dengan jumlah unit usaha sebesar 56.534.592 unit daripada usaha besar yang hanya menguasai $0,01 \%$ pangsa pasar dengan jumlah unit usaha sebesar 4.968 unit. Hal ini juga menunjukkan, tingkat pengangguran di Indonesia dapat terserap lebih banyak di sektor UMKM dan memiliki peran sentral dalam perekonomian di saat masa krisis dan pasca krisis.

Menurut data hasil survey BPS, nilai output yang dihasilkan industri mikro dan kecil dari tahun 2018 sampai dengan tahun 2019 meningkat 6 kali lipat dari 83.095.179 menjadi 489.898.331 di tahun 2019. Hal ini menunjukkan kinerja Usaha Mikro Kecil Menengah di Indonesia meningkat secara signifikan setiap tahunnya dan tentu saja akan membawa dampak bagi perekenomian di Indonesia menjadi semakin berkembang.

Didasarkan atas kondisi UMKM tersebut, jumlah usaha mikro kecil menengah (UMKM) mempunyai banyak pesaing di bidang usahanya. Selain persaingan yang ketat, ternyata pelaku usaha UMKM masih menghadapi masalah-masalah diantaranya kurangnya modal sendiri, sulitnya dalam memasarkan produk, kesulitan mendapatkan bahan baku, kurangnya teknis produksi dan keahlian, kurangnya keterampilan manajerial (SDM) dan kurangnya pengetahuan dalam masalah manajemen khususnya bidang keuangan dan akuntansi [1]. Oleh karena itu, pentingnya UMKM dalam meningkatkan kinerjanya sangat dibutuhkan untuk bertahan dalam persaingan usaha yang ketat ini dan mampu mengembangkan usahanya menjadi lebih besar.

\section{METODE}

Jenis penelitian yang digunakan adalah explanatory research. Sampel dalam penelitian ini adalah 84 orang responden yang menjadi pemilik UMKM diambil secara incidental sampling. Instrumen penelitian dengan menggunakan kuesioner. Analisis yang digunakan adalah analisis regresi linier berganda, dimana X1 menunjuk pada variabel entrepreneurship, $\mathrm{X} 2$ pada market oriented, Y1 pada keunggulan bersaing, dan Y2 pada kinerja pemasaran online shop.

Sebagaimana yang telah diuraikan bahwa kinerja usaha merupakan aspek yang menunjukkan seberapa besar pertumbuhan usaha yang dijalankan. Berbagai penelitian menunjukkan ada empat faktor penting yang mendukung terbentuknya kinerja pemasaran online shop yaitu market oriented, entrepreneurship, inovasi produk dan keunggulan bersaing. Perkembangan UMKM di daerah Malang sendiri berkembang cukup pesat beberapa tahun terakhir ini karena dicanangkannya Malang sebagai kabupaten pariwisata. Oleh karena itu, pentingnya pelaku usaha UMKM untuk meningkatkan kinerja usaha yang dijalankan dengan mengembangkan entrepreneurship, market oriented dan keunggulan bersaing melalui ikut serta aktif dalam berbagai macam bentuk pelatihan baik yang dicanangkan lembaga pemerintah maupun swasta. Berikut disajikan kerangka konsep pada Gambar 1. 


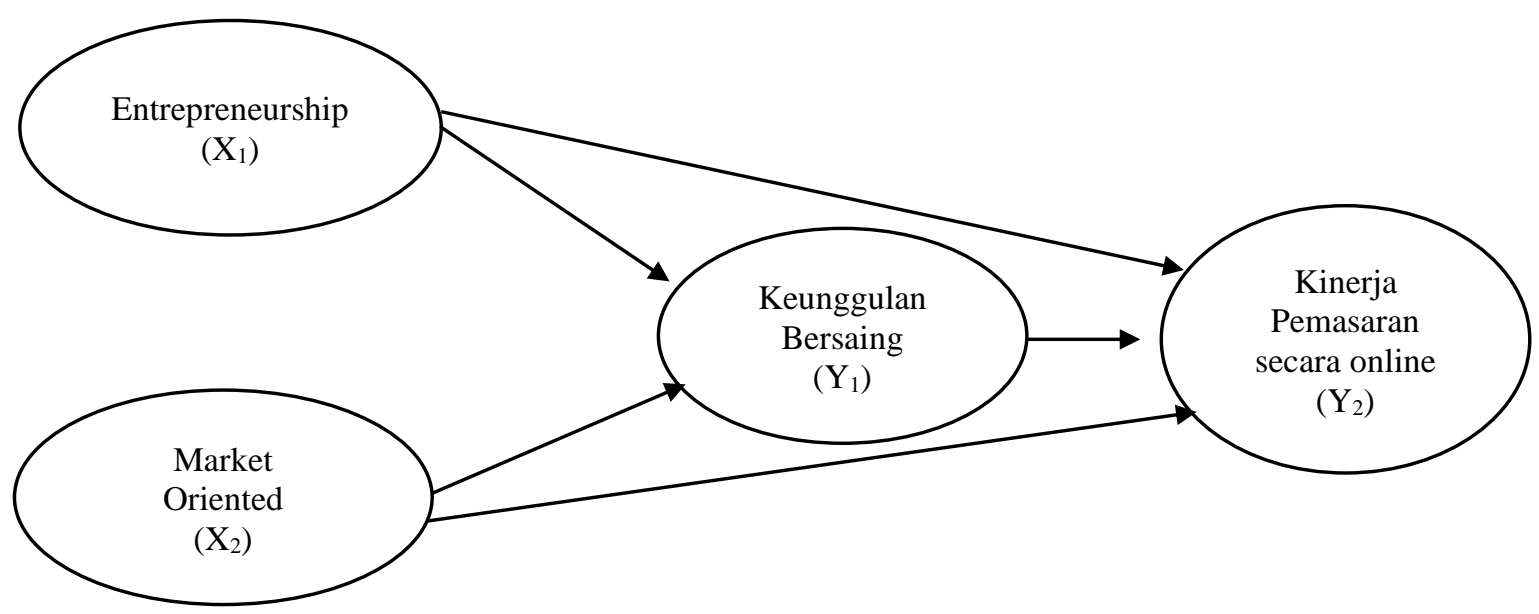

Gambar 1. Kerangka konsep penelitian

Hipotesis 1 adalah entrepreneurship $\left(\mathrm{X}_{1}\right)$ secara signifikan berkorelasi positif terhadap kinerja pemasaran $\left(\mathrm{X}_{2}\right)$. Hipotesis 2 adalah entrepreneurship $\left(\mathrm{X}_{1}\right)$ secara signifikan berkorelasi positif terhadap keunggulan bersaing $\left(\mathrm{Y}_{1}\right)$. Hipotesis 3 adalah market oriented $\left(\mathrm{X}_{2}\right)$ secara signifikan berkorelasi positif terhadap keunggulan bersaing ( $\left.\mathrm{Y}_{1}\right)$. Hipotesis 4 adalah market oriented $\left(\mathrm{X}_{2}\right)$ secara signifikan berkorelasi positif terhadap kinerja pemasaran $\left(\mathrm{Y}_{2}\right)$. Hipotesis 5 adalah keunggulan bersaing $\left(\mathrm{Y}_{1}\right)$ secara signifikan berkorelasi positif terhadap kinerja pemasaran $\left(\mathrm{Y}_{2}\right)$.

\section{HASIL DAN PEMBAHASAN}

\section{Pengaruh Entrepreneurship Terhadap Keunggulan Bersaing}

Hasil penelitian menunjukkan bahwa terdapat pengaruh entrepreneurship terhadap keunggulan bersaing. Hal ini didukung dengan nilai koefisien regresi entrepreneurship adalah sebesar 0,634 dan nilai t hitung sebesar 7,732 > t tabel dengan tingkat signifikan $(0,000)<$ 0,05. Dengan demikian dapat disimpulkan bahwa hipotesis kedua diterima. Dengan demikian dalam penelitian ini ditemukan bahwa ada pengaruh yang positif dan signifikan entrepreneurship terhadap keunggulan bersaing.

Porter [2] mendefinisikan entrepreneurship sebagai strategi benefit perusahaan untuk dapat berkompetisi secara lebih efektif di dalam market place yang sama. Entrepreneurship mengacu pada proses, praktik, dan pengambilan keputusan yang mendorong ke arah input baru dan mempunyai tiga aspek kewirausahaan, yaitu selalu inovatif, bertindak secara proaktif dan berani mengambil risiko [3].

Kewirausahaan disebut sebagai sprearhead (pelopor) untuk mewujudkan pertumbuhan ekonomi perusahaan berkelanjutan dan berdaya saing tinggi [4]. Kemampuan inovasi berhubungan dengan persepsi dan akitvitas terhadap aktivitas - aktivitas bisnis yang baru dan unik. Kemampuan berinovasi adalah titik penting kewirausahaan dan esensi dari karakteristik kewirausahaan. Beberapa hasil penelitian dan literatur kewirausahaan menunjukan bahwa entrepreneurship lebih signifikan mempunyai kemampuan inovasi daripada yang tidak memiliki kemampuan dalam kewirausahaan.

Proaktifitas seseorang untuk berusaha berprestasi merupakan petunjuk lain dari aplikasi atas entrepreneurship secara pribadi. Demikian pula bila suatu perusahaan menekankan proaktifitas dalam kegiatan bisnisnya, maka perusahaan tersebut telah melakukan aktivitas kewirausahaan yang akan secara otomatis mendorong tingginya kinerja. Perusahaan dengan aktivitas kewirausahaan yang tinggi berarti tampak dari tingginya semangat yang tidak pernah pada karena hambatan, rintangan, dan tantangan. Sesorang berani mengambil risiko dapat 
didefinisikan sebagai seseorang yang berorientasi pada peluang dalam ketidakpastian konteks pengambilan keputusan. Hambatan risiko merupakan faktor kunci yang membedakan perusahaan dengan jiwa wirausaha dan tidak. Fungsi utama dari tingginya entrepreneurship adalah bagaimana melibatkan pengukuran risiko dan pengambilan risiko secara optimal.

Perusahaan yang melakukan entrepreneurship akan mampu berinovasi sehingga dapat menciptakan produk yang lebih unik / menarik dibanding dengan pesaingnya. Perusahaan juga akan berani mengambil resiko dalam pengambilan keputusan yang belum pasti namun memberikan peluang untuk hasil yang lebih baik. Sifat proaktif mencari pasar dilakukan guna mendapatkan pasar yang lebih luas ditengah persaingan.

\section{Pengaruh Market oriented terhadap Keunggulan Bersaing}

Hasil penelitian menunjukkan bahwa terdapat pengaruh market oriented terhadap keunggulan bersaing. Hal ini didukung dengan nilai koefisien regresi adalah sebesar 0,180 dan nilai t hitung sebesar 2,198 $>\mathrm{t}$ tabel dengan tingkat signifikan $(0,031)<0,05$. Dengan demikian dapat disimpulkan bahwa hipotesis ketiga diterima. Dengan demikian dalam penelitian ini ditemukan bahwa ada pengaruh yang positif dan signifikan market oriented terhadap keunggulan bersaing.

Market oriented $($ marketorientation $=\mathrm{MO}$ ) merupakan ukuran perilaku dan aktivitas yang mencerminkan implementasi konsep pemasaran. Narver dan Slater [5] menyatakan bahwa market oriented adalah budaya organisasi yang paling efektif dalam menciptakan perilaku penting untuk penciptaan nilai unggul bagi pembeli serta kinerja dalam bisnis. Market oriented merupakan sesuatu yang penting bagi perusahaan sejalan dengan meningkatnya persaingan global dan perubahan dalam kebutuhan pelanggan dimana perusahaan menyadari bahwa mereka harus selalu dekat dengan pasarnya. Konsep pemasaran menyatakan bahwa untuk mencapai tujuan organisasi seperti market share dan profitabilitas tergantung pada kemampuan perusahaan dalam menentukan kebutuhan dan keinginan pasar sasaran dan memuaskannya dengan lebih efektif dan efisien dibandingkan dengan para pesaingnya.

\section{Pengaruh Market Oriented terhadap Kinerja Pemasaran Online Shop}

Hasil penelitian menunjukkan bahwa terdapat pengaruh market oriented terhadap kinerja pemasaran online shop. Hal ini didukung dengan nilai koefisien regresi market oriented adalah sebesar 0,151 dan nilai t hitung sebesar 2,727 > t tabel dengan tingkat signifikan $(0,008)<0,05$. Dengan demikian dapat disimpulkan bahwa hipotesis ketiga diterima. Dengan demikian dalam penelitian ini ditemukan bahwa ada pengaruh yang positif dan signifikan market oriented terhadap kinerja pemasaran online shop.

Market oriented mencerminkan kompetensi dalam memahami pelanggan, karena itu mempunyai peluang memberi kepuasan pada pelanggan sama halnya dengan kemampuannya dalam mengenali gerak gerik pesaingnya. Perusahaan yang berhasil dalam mengendalikan pasar disebut sebagai "market drive firm" yaitu perusahaan yang selalu menempatkan orientasi pelanggan dan orientasi pesaing secara harmonis sehingga menghasilkan kinerja pemasaran online shop yang lebih baik. Dimensi utama dalam market oriented adalah orientasi pelanggan dan orientasi pesaing. Perusahaan yang memiliki tingkat market oriented yang tinggi akan memiliki kinerja pemasaran online shop yang tinggi, karena perusahaan yang memiliki derajat market oriented yang tinggi akan memiliki keunggulan kompetitif dalam hal; kualitas produk, kualitas pelayanan, inovasi produk dan biaya [6].

\section{Pengaruh Keunggulan Bersaing Terhadap Kinerja Pemasaran}

Hasil penelitian menunjukkan bahwa terdapat pengaruh keunggulan bersaing terhadap kinerja pemasaran online shop. Hal ini didukung dengan nilai koefisien regresi keunggulan bersaing adalah sebesar 0,271 dan nilai t hitung sebesar 3,718 > t tabel dengan tingkat signifikan $(0,000)<0,05$. Dengan demikian dapat disimpulkan bahwa hipotesis kelima 
diterima. Dengan demikian dalam penelitian ini ditemukan bahwa ada pengaruh yang positif dan signifikan keunggulan bersaing terhadap kinerja pemasaran online shop.

Keunggulan bersaing merupakan hasil dari implementasi strategi yang memanfaatkan berbagai sumberdaya yang dimiliki perusahaan [7]. Keahlian dan asset yang unik dipandang sebagai sumber dari keunggulan bersaing. Keahlian unik merupakan kemampuan perusahaan untuk menjadikan para karyawannya sebagai bagian penting dalam mencapai keunggulan bersaing. Keunggulan bersaing menurut [8] adalah sekumpulan faktor yang membedakan perusahaan kecil dari para pesaingnya dan memberikannya posisi unik di pasar sehingga lebih unggul dari pada pesaingnya.

Setiap perusahaan yang bersaing dalam suatu lingkungan industri mempunyai keinginan untuk dapat lebih unggul dibandingkan pesaingnya. Umumnya perusahaan menerapkan strategi bersaing ini secara eksplisit melalui kegiatan-kegiatan dari berbagai departemen fungsional perusahaan yang ada. Perusahaan yang memiliki kompetensi dalam bidang pemasaran, manufacturing, dan inovasi dapat menjadikannya sebagai sumber-sumber untuk mencapai keunggulan bersaing. Perusahaan yang terus memperhatikan perkembangan kinerjanya dan berupaya untuk meningkatkan kinerja tersebut memilki peluang mencapai posisi persaingan yang baik maka sebenarnya perusahaan telah memilki modal yang kuat untuk terus bersaing dengan perusahan lain.

Keunggulan bersaing dapat diperoleh dari kemampuan perusahaan untuk mengelola dan memanfaatkan sumber daya dan modal yang dimilikinya. Perusahaan yang mampu menciptakan keunggulan bersaing akan memiliki kekuatan untuk bersaing dengan perusahaan lainnya karena produknya akan tetap diminati pelanggan. Dengan demikian keunggulan bersaing memiliki pengaruh positif terhadap peningkatan kinerja pemasaran online shop.

\section{SIMPULAN DAN SARAN}

Entrepreneurship berpengaruh positif dan signifikan terhadap kinerja pemasaran online shop. Berdasarkan hasil penelitian diketahui bahwa hasil menunjukkan uji statistik dan uji t serta nilai signifikansi diketahui bahwa entrepreneurship berpengaruh positif terhadap kinerja usaha pada Usaha Menengah Kecil Mikro (UMKM) Kota Malang.

Entrepreneurship berpengaruh positif terhadap keunggulan bersaing. Berdasarkan hasil penelitian diketahui bahwa hasil menunjukkan uji statistik dan uji t serta nilai signifikansi diketahui bahwa entrepreneurship berpengaruh positif terhadap keunggulan bersaing pada Usaha Mikro Kecil Menengah (UMKM) di Kota Malang. Hal ini juga didukung dalam penelitian Fatmawati [9] bahwa entrepreneurship berpengaruh positif dan signifikan terhadap keunggulan bersaing dan penelitian Reniati yang menyatakan bahwa kompetensi kewirausahaan berpengaruh positif dan signifikan terhadap keunggulan bersaing. Hal ini didukung oleh Nakhata [10] bahwa 10 dimensi kompetensi kewirausahaan yang dibangun berpengaruh terhadap kesuksesan seorang wirausaha dalam mengelola bisnis.

Market oriented berpengaruh positif terhadap keunggulan bersaing. Berdasarkan hasil penelitian diketahui bahwa hasil menunjukkan uji statistik dan uji t serta nilai signifikansi diketahui bahwa market oriented berpengaruh positif terhadap keunggulan bersaing pada Usaha Mikro Kecil Menengah (UMKM) di Kota Malang . hasil penelitian ini sejalan dengan penelitian Fatmawati [9] yang membuktikan bahwa market oriented berpengaruh terhadap keunggulan bersaing.

Market oriented berpengaruh positif terhadap kinerja pemasaran online shop. Berdasarkan hasil penelitian diketahui bahwa hasil menunjukkan uji statistik dan uji t serta nilai signifikansi diketahui bahwa market oriented berpengaruh positif dan signifikan terhadap kinerja pemasaran pada online shop. Hal itu menunjukkan bahwa market oriented berpengaruh positif terhadap keunggulan bersaing pada Usaha Mikro Kecil Menengah (UMKM) di Kota Malang. Hasil penelitian ini sejalan dengan penelitian sebelumnya Fatmawati [9] yang membuktikan bahwa market oriented berpengaruh signifikan dan berkorelasi positif terhadap kinerja pemasaran pada online shop dan juga didukung dengan 
penelitian terdahulu oleh Dermawan [11] yang membuktikan adanya pengaruh market oriented terhadap kinerja usaha.

Keunggulan bersaing berpengaruh positif terhadap kinerja pemasaran pada online shop. Berdasarkan hasil penelitian diketahui bahwa hasil menunjukkan uji statistik dan uji t serta nilai signifikansi diketahui bahwa keunggulan bersaing berpengaruh positif dan signifikan terhadap kinerja pemasaran online shop. Hal ini menunjukkan bahwa keunggulan bersaing berpengaruh positif terhadap kinerja pemasaran pada Usaha Mikro Kecil Menengah (UMKM) di Kota Malang. Hasil penelitian ini sejalan dengan penelitian sebelumnya hasil penelitian ini sejalan dengan penelitian sebelumnya Fatmawati [9] yang membuktikan bahwa keunggulan bersaing berpengaruh signifikan dan berkorelasi positif terhadap kinerja pemasaran dan penelitian sebelumnya Aji [12] yang membuktikan bahwa daya saing berpengaruh signifikan dan berkorelasi positif terhadap kinerja pemasaran pada online shop.

\section{DAFTAR PUSTAKA}

[1] E. Hadiyati, "Pemasaran untuk UMKM (Teori dan Aplikasi)," Ed. Pertama, Cetakan Pertama, Malang Bayumedia, 2010.

[2] M. E. Porter, On competition. Harvard Business Press, 2008.

[3] G. T. Lumpkin, "dan Dess, GG 1996," Clarifying Entrep. Orientat. Constr. Link. it to Perfomance, Acad. Manag. Rev., vol. 33, no. 1, pp. 135-172.

[4] A. Suryanita, "Analisis Pengaruh Orientasi Kewirausahaan Dan Kompetensi Pengetahuan Terhadap Kapabilitas Untuk Meningkatkan Kinerja Pemasaran (Studi Empirik Pada Industri Pakaian Jadi Di Kota Semarang)." Program Pascasarjana Universitas Diponegoro, 2006.

[5] J. C. Narver and S. F. Slater, "The effect of a market orientation on business profitability," J. Mark., vol. 54, no. 4, pp. 20-35, 1990.

[6] H. Hart and S. Sittimalakorn, "Market OrientationVersus Quality Orientation: Sucess of Superior Business Performance,” J. Strateg. Manag., pp. 12243-12253, 2004.

[7] S. G. Bharadwaj, P. R. Varadarajan, and J. Fahy, "Sustainable competitive advantage in service industries: a conceptual model and research propositions," J. Mark., vol. 57, no. 4, pp. 83-99, 1993.

[8] N. M. Scarborough, T. Zimmerer, and D. Wilson, Essentials of Entrepreneurship and Small Business Management: Instructor's Manual with Test Item File \& Video Guide. Pearson Prentice Hall, 2008.

[9] R. A. Fatmawati, A. Pradhanawati, and N. Ngatno, "Pengaruh Orientasi Pasar, Orientasi Kewirausahaan Terhadap Keunggulan Bersaing dan Kinerja Pemasaran Pada Warung Kucingan/Angkringan Di Kota Semarang,” J. Ilmu Adm. Bisnis, vol. 5, no. 3, pp. 351$362,2016$.

[10] C. Nakhata, "The relationships between human capital, entrepreneurial competencies and career success of SME entrepreneurs in Thailand," AU J. Manag., vol. 5, no. 1, pp. 17-26, 2007.

[11] R. Dermawan, "Pengaruh Orientasi Kewirausahaan, Orientasi Pasar, dan Kemampuan Manajemen terhadap Peningkatan Kinerja Perusahaan Studi Kasus pada Usaha Mikro Kecil Menengah di Kota Malang," STIE Malangkcecwara, 2015.

[12] W. P. Aji and Y. SUGIARTO, "Analisis Pengaruh Orientasi Pasar, Orientasi Kewirausahaan, Dan Daya Saing Terhadap Kinerja Pemasaran Industri Knalpot (Studi Pada Home Industri Knalpot di Kabupaten Purbalingga)." Fakultas Ekonomika dan Bisnis, 2014. 